\title{
DNA extraction and quantification from touch and scrape preparations obtained from autopsy liver cells
}

C.N.M. Ribeiro ${ }^{1}$,

L.C. Peres ${ }^{1}$ and

J.M. Pina-Neto ${ }^{2}$
Departamentos de ${ }^{1}$ Patologia and ${ }^{2}$ Genética,

Faculdade de Medicina de Ribeirão Preto,

Universidade de São Paulo, Ribeirão Preto, SP, Brasil

\section{Correspondence}

L.C. Peres

Departamento de Patologia

FMRP, USP

Av. Bandeirantes, 3900

14049-900 Ribeirão Preto, SP

Brasil

Fax: +55-16-633-1068

E-mail: Icperes@fmrp.usp.br

Research supported by CAPES

(No. DS103/004).

Publication supported by FAPESP

Received February 19, 2003 Accepted December 8, 2003

\begin{abstract}
The objective of the present study was to develop a simplified low cost method for the collection and fixation of pediatric autopsy cells and to determine the quantitative and qualitative adequacy of extracted DNA. Touch and scrape preparations of pediatric liver cells were obtained from 15 cadavers at autopsy and fixed in 95\% ethanol or $3: 1$ methanol:acetic acid. Material prepared by each fixation procedure

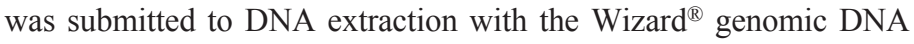
purification kit for DNA quantification and five of the preparations were amplified by multiplex PCR (azoospermia factor genes). The amount of DNA extracted varied from 20 to $8,640 \mu \mathrm{g}$, with significant differences between fixation methods. Scrape preparation fixed in $95 \%$ ethanol provided larger amount of extracted DNA. However, the mean for all groups was higher than the quantity needed for PCR (50 ng) or Southern blot (500 ng). There were no qualitative differences among the different material and fixatives. The same results were also obtained for glass slides stored at room temperature for 6, 12, 18 and 24 months. We conclude that touch and scrape preparations fixed in $95 \%$ ethanol are a good source of DNA and present fewer limitations than cell culture, tissue paraffin embedding or freezing that require sterile material, culture medium, laboratory equipment and trained technicians. In addition, they are more practical and less labor intensive and can be obtained and stored for a long time at low cost.
\end{abstract}

Key words - Autopsy

- Congenital anomalies

- DNA

- Touch preparative

- Scrape preparative

- Polymerase chain reaction

\section{Introduction}

Congenital anomalies are structural, functional, biochemical or behavioral alterations observable at birth. They involve about 3\% of liveborns in the general population (1) and represent the major cause of post-neonatal death in the city of Ribeirão Preto (2), corresponding to about $25 \%$ of the cases of pediatric autopsy at the University Hospital of the Faculty of Medicine of Ribeirão Preto, University of São Paulo (3).

Although many of the anomalies observed at autopsy can be diagnosed by dysmorphologic examination to establish the syndromic and etiological diagnosis, other procedures are often necessary, ranging from cytogenetics to biochemical and/or molecular genetic techniques. Cytogenetics is of great value for the study of congenital anomalies, especially 
those presenting multiple defects, but requires the presence of viable cells and an appropriately equipped laboratory. Its disadvantages are a high cost, time-consuming procedures (4) and limitation by lack of growth or by contamination with bacteria and fungi (5). In addition, non-numerical chromosome alterations or alterations below the level of optical resolution (microdeletions) cannot be identified by this method but require molecular techniques.

DNA can be extracted from different tissues, fixed or not. The choice of a method should consider not only the quality and quantity of extracted DNA, but also the costs of collection, preservation and storage. Touch and scrape preparatives are easy to obtain at autopsy and can be obtained from different tissues, providing a large number of samples (6-8). They do not require complicated technical training and require only new and clean glass slides $(9,10)$ and a fixative fluid, materials of low cost. Fixation can be performed with ethanol, acetone, methanol or by air drying, among other techniques, with care taken to always preserve DNA integrity $(11,12)$. The slides thus obtained can be stored for long periods of time at room temperature (13) and also provide a large number of whole cells with intact nuclei, which can be recovered for DNA extraction for different purposes.

Touch and scrape preparatives are useful means of obtaining material for molecular studies and can be easily obtained from patients, for example, by washes or scrape preparatives of the oral cavity (14-16). However, this cell source is not adequate at autopsy since the oral cavity presents marked contamination with cells and food debris and biological agents such as bacteria and fungi that may impair certain analyses. On the other hand, at autopsy it is possible to obtain better preserved cells, with a lower risk of tissue contamination with foreign elements. Thus, liver touch and scrape preparatives represent an excellent cell source.
The objective of the present study was to define and validate a method for the collection and fixation of liver cells obtained by touch and scrape preparatives at autopsy for DNA extraction and amplification for the purpose of diagnosing congenital anomalies and other genetic diseases.

\section{Material and Methods}

The touch and scrape preparatives used in the present study were obtained from 15 children of both sexes ranging in age from 25 min to four years who presented some type of congenital anomaly, and submitted to autopsy at the Pathology Service of the University Hospital, Faculty of Medicine of Ribeirão Preto (HCFMRP-USP), from July to December 2001. The project was approved by the Research Ethics Committee of HCFMRPUSP.

A fragment of the left liver lobe measuring approximately $4 \times 3 \times 0.5 \mathrm{~cm}$ was removed from each liver and its surface was used for the collection of touch (group TP) and scrape preparatives (group SP). The fragments were first washed in running water to remove excess blood and 4 touch preparatives were then performed by simply pressing new and clean microscope slides against the surface of the fragment. Scrape preparatives were then obtained with a new and clean surgical knife blade and deposited on three new and clean microscope slides.

Immediately after collection, the slides were placed in appropriate plastic tubes containing 95\% ethanol for $10 \mathrm{~min}$ (groups TP95 and SP95) or 3:1 methanol:glacial acetic acid solution for $45 \mathrm{~s}$ (groups TPMA and SPMA). After fixation, the slides were air dried, wrapped in polypropylene film and stored in cardboard boxes at room temperature until the next stage of the experiment.

DNA was extracted using the Wizard $^{\circledR}$ genomic DNA purification kit (Promega Corporation, Madison, WI, USA). Cells were carefully removed by scraping from a single touch 
or scrape preparative slide with the aid of a new sterile surgical knife blade and the material obtained was placed in new clean $1.0-\mathrm{ml}$ Eppendorf microtube to which $300 \mu$ cell lysis solution, $100 \mu \mathrm{l}$ nucleus lysis solution and $20 \mu \mathrm{l}$ proteinase $\mathrm{K}(20 \mathrm{mg} / \mathrm{ml}$, Promega) were added. The mixture was incubated overnight in a water bath at $50^{\circ} \mathrm{C}$, and $35 \mu \mathrm{l}$ of the protein precipitation solution of the kit (not specified by the manufacturer) was then added and the sample kept in an ice bath for $5 \mathrm{~min}$. Next, the mixture was centrifuged at $15,600 \mathrm{~g}$ for $4 \mathrm{~min}$, the supernatant was transferred to a microtube containing $300 \mu \mathrm{l} 100 \%$ isopropanol, mixed by inversion, and again centrifuged for $1 \mathrm{~min}$ and the supernatant was discarded. The pellet was resuspended in $300 \mu \mathrm{l}$ $70 \%$ ethanol and centrifuged at $15,600 \mathrm{~g}$ for 1 min, and the supernatant was discarded. The pellet was air dried and then hydrated with 20 $\mu 1$ hydration solution. Finally, the extracted DNA was stored at $-20^{\circ} \mathrm{C}$.

DNA was quantified at 1:100 dilution with a GeneQuant II RNA/DNA calculator spectrophotometer (Pharmacia Biotech, Cambridge, UK) at $260 \mathrm{~nm}$ wavelength for determination of double-stranded DNA.

DNA was amplified by PCR in five cases from each group in order to determine the quality of extracted DNA. A multiplex PCR system with a primer mix for the study of azoospermia factor - AZF (Yq11) was used (Table 1) and for this reason all subjects studied were males.

PCR was performed using $3 \mu \mathrm{l}$ DNA, 0.8 $\mu 1$ Taq (Thermus aquaticus) DNA Poly- merase (Gibco-BRL, Gaithersburg, MD, USA), $10.45 \mu 1 \mathrm{ddp}$ water, $5 \mu \mathrm{l}$ Taq DNA polymerase buffer (Gibco), $2.5 \mu 12 \mathrm{mM}$ deoxyribonucleotide 5 ' triphosphate, $1.25 \mu 1$ dimethylsulfoxide, and $2 \mu 1$ primer mix, placed in a PTC-100 thermocycler (MJ Research Inc., Watertown, MA, USA). The following cycles were used: $94^{\circ} \mathrm{C} / 5 \mathrm{~min}$, $94^{\circ} \mathrm{C} / 30 \mathrm{~s}, 52^{\circ} \mathrm{C} / 45 \mathrm{~s}$, and $65^{\circ} \mathrm{C} / 2 \mathrm{~min}$, with 44 repetitions starting from the second step, and a final cycle at $65^{\circ} \mathrm{C} / 5 \mathrm{~min}$.

After amplification, $5 \mu 1$ of the material was stained with Orange $G$ and submitted to $1.5 \%$ agarose gel electrophoresis (Gibco) in Tris borate EDTA with $5 \mu$ l ethidium bromide at $80 \mathrm{~V}$ for a maximum of $1 \mathrm{~h}$ using a 100-bp ladder as a molecular weight marker. The result was photographed with a Kodak digital camera.

To test if long-term storage affected the amount and quality of the extracted DNA, one slide each of touch and scrape preparatives with both fixatives, stored for $6,12,18$ and 24 months on cardboard at room temperature, was submitted to the procedures described above.

\section{Statistical analysis}

Data were analyzed statistically using the GMC software. When testing for normality we observed that the experimental data were not normally distributed and therefore we opted for the Kruskal-Wallis test for analysis of variance of multiple independent samples.

\begin{tabular}{lllll}
\multicolumn{2}{l}{ Table 1. Primers used in multiplex PCR. } \\
\hline Name & Locus & Direct primer & Inverse primer & bp \\
\hline Y6D14pr & DYS205 & GGCTAGGTGCCAGCAAGTAGATCA & GTTCTCTTCCCCTGCATCAAG & 134 \\
Y6BaH34pr & DYS206 & GCCCTTTGGTAAAGCG & GAATTTGCAAGGCTGC & 910 \\
Y6Hp35pr & DYS274 & GGTACACACTCCATCCTGGAC & TAACGGCTACCTTTTAGGTGG & 226 \\
Y6Hp52pr & DYS239 & GAACTGGCAGGATTAGCCTTC & GCTCAGAATCTGCGATCAG & 258 \\
Fr15-Hpr & ND & TAGCTTGGTTTTGCACCAGACGC & CACCCTCTGTATATGACCTGGC & 313 \\
& & & &
\end{tabular}

$N D=$ not determined 
Table 2. Concentration in $n g / \mu l$ of DNA extracted from the different samples (total volume of each, $20 \mu l)$.

\begin{tabular}{lrrr}
\hline \multicolumn{4}{c}{ Groups } \\
\hline TP95 & TPMA & SP95 & SPMA \\
\hline 90 & 420 & 460 & 50 \\
1,165 & 1,950 & 7,500 & 3,680 \\
1,160 & 20 & 8,550 & 30 \\
4,170 & 20 & 8,640 & 50 \\
560 & 885 & 450 & 3,980 \\
340 & 2,580 & 2,960 & 1,210 \\
1,585 & 335 & 4,670 & 6,540 \\
455 & 265 & 1,430 & 2,980 \\
90 & 1,195 & 130 & 50 \\
775 & 395 & 7,500 & 500 \\
1,725 & 1,095 & 8,360 & 90 \\
985 & 775 & 2,090 & 1,040 \\
520 & 215 & 2,070 & 2,970 \\
1,200 & 250 & 3,400 & 1,900 \\
1,250 & 355 & 3,700 & 1,540 \\
Means & \multicolumn{4}{c}{} \\
$1,071.33$ & 717 & $4,127.33$ & 1,774 \\
\hline TP $=$ touch & preparatives; SP $=$ scrape & prepara- \\
tives; $95=95 \%$ ethanol; MA $=$ methanol:glacial \\
acetic acid (3:1).
\end{tabular}

Table 3. Kruskal-Wallis test for the comparison of sample rank means.

\begin{tabular}{lcc}
\hline $\begin{array}{l}\text { Samples } \\
\text { compared }\end{array}$ & $\begin{array}{c}\text { Differences } \\
\text { between means }\end{array}$ & Significance \\
\hline TP95 $\times$ TPMA & 7.3333 & $\mathrm{~ns}$ \\
TP95 $\times$ SP95 & 16.5000 & 0.01 \\
TP95 $\times$ SPMA & 1.7667 & $\mathrm{~ns}$ \\
TPMA $\times$ SP5 & 23.8333 & 0.001 \\
TPMA $\times$ SPMA & 9.1000 & $\mathrm{~ns}$ \\
SP95 $\times$ SPMA & 14.7333 & 0.05 \\
\hline
\end{tabular}

$\mathrm{TP}=$ touch preparatives; $\mathrm{SP}=$ scrape preparatives; $95=95 \%$ ethanol; $\mathrm{MA}=$ methanol:glacial acetic acid (3:1); ns = nonsignificant.

Table 4. DNA extracted from different samples stored for different times.

\begin{tabular}{lcccc}
\hline Samples & \multicolumn{4}{c}{ Storage time in months } \\
\cline { 2 - 5 } & 6 & 12 & 18 & 24 \\
\hline TPMA & 4,630 & - & - & 2,320 \\
SP95 & 5,000 & - & - & 5,160 \\
SPMA & - & 4,670 & 2,390 & - \\
TP95 & - & 6,540 & 2,330 & - \\
\hline TP = touch preparatives; SP $=$ & scrape prepara- \\
tives; 95 = 95\% ethanol; MA $=$ methanol:glacial \\
acetic acid (3:1).
\end{tabular}

\section{Results}

Touch or scrape preparatives were easily obtained in all cases, usually with good quality material. However, some of the slides showed large amounts of blood and in many cases, after fixation, they exhibited a turbid coloration of the fixative, indicating that part of the material had remained diluted in the latter. In other cases there was little material adhered to the slides even before they were placed in the fixative.

DNA extraction by the methodology used was efficient, as can be seen in Table 2, which shows the results of quantification for the 15 samples studied in each group. There was wide variation among touch and scrape preparative samples and between fixatives from 20 to $8,640 \mathrm{ng} / \mu \mathrm{l}$, with a mean of $1,071.33 \mathrm{ng} / \mu 1$ for TP95, $717 \mathrm{ng} / \mu 1$ for TPMA, 4,127.33 ng/ $\mu 1$ for SP95, and 1,774 $\mathrm{ng} / \mu \mathrm{l}$ for SPMA.

Pair-wise comparison of the samples (Table 3) showed that there was a significant difference between TP95 and SP95, TPMA and SP95 and SP95 and SPMA, indicating that $95 \%$ ethanol is a better fixative than methanol:acetic acid and that scrape preparatives are better than touch preparatives. Comparison of TP95 and TPMA, TP95 and SPMA and TPMA and SPMA showed no significant differences at the $5 \%$ level.

With respect to the quality of the extracted DNA, PCR amplification with the primers used showed that there were no differences between fixatives and materials, as illustrated in Figure 1.

Table 4 shows the results of quantification of DNA extracted from long-term storage slides. The amount was similar to what was obtained with shorter storage time.

PCR amplification done on the DNA extracted from long-term storage at room temperature showed no difference when compared to short-term storage (data not shown). 


\section{Discussion}

Congenital anomalies require attention and more in-depth studies since they are appearing at increasing frequency, not only in our region (2), but also in general in the Brazilian Southeast and in developed countries (17). This frequency tends to increase as avoidable causes of death such as prematurity, infections and malnutrition are better controlled, and also with better pre- and postnatal care. Thus, only causes of death of more difficult control persist; particularly important among them are congenital anomalies $(3,17)$.

Paraffin-embedded tissue can be used as a source of cells for DNA extraction, although not all of them are susceptible to PCR and some fail to yield detectable products $(18,19)$. The explanation for this failure is unknown, but may be due to differences in fixation. The use of $10 \%$ buffered formalin for more than 3 days reduces amplification (18). Shorter times of fixation can reduce the quantity of amplified material (19). The amount of DNA decreased progressively when non-fixed frozen sections, frozen sections fixed with $10 \%$ formalin for $10 \mathrm{~min}$ and paraffin-embedded sections were compared in terms of DNA extraction (19). The deleterious action of formalin is due to DNA cross-linking with proteins $(20,21)$, which increases with time of fixation (11), as also observed for RNA (22). The quality of DNA extracted from paraffin-embedded tissue may also be inadequate due to the presence of phenols, salts, EDTA (23), paraffin, formalin $(19,23)$, and substances used for staining (19). Thus, the degraded DNA generates an unknown amount of amplified products (23), usually smaller than that obtained with ethanol (24). Amplified products of up to $250 \mathrm{bp}$ can be obtained from histological sections of tissues previously fixed in formalin and embedded in paraffin (25).

Cell culture, which would guarantee excellent material for molecular studies, is of lim- ited application because it is usually employed only in specific cases such as multiple congenital anomalies. It is an expensive and timeconsuming procedure which may also result in lack of growth and in contamination $(1,3,5)$.

Another adequate source both in terms of quantity and quality is tissue fragments which are frozen in liquid nitrogen and stored frozen at very low temperatures (26-29), a procedure that involves relatively high costs.

The present results show that the use of liver touch and scrape preparatives can be a good alternative because of the simple methodology involved, the amount and quality of the material obtained and the low cost of obtaining and storing the material, which is not impaired by long-term storage at room temperature. Touch and scrape preparatives vary widely in the amount of DNA extracted, possibly as a function of the presence of blood or even of inadequate adherence of the material to the slide (30), with the material being lost when the slide is placed in the fixative, with consequent turbidity of the fluid. To avoid this problem, the fragment could be washed in saline to remove most of the blood, and the surface to be used should

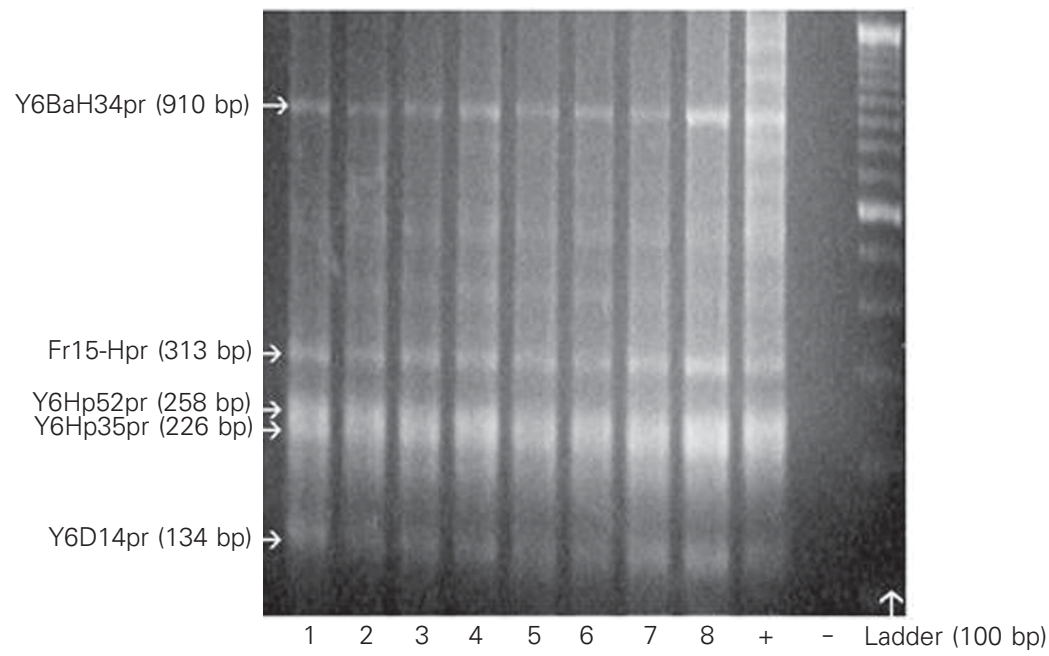

Figure 1. Amplification on $1.5 \%$ agarose gel of DNA extracted from touch and scrape liver preparatives at a concentration of $600 \mathrm{ng} / \mathrm{\mu l}$. Lanes: 1 , SP95\%; 2, SPMA; 3, SP95\%; 4 SPMA; 5, TP95\%; 6, TPMA; 7, TP95\%; 8, TPMA; +, positive control; - negative control; Ladder $100 \mathrm{bp} . \mathrm{TP}=$ touch preparatives; $\mathrm{SP}=$ scrape preparatives; $95 \%=95 \%$ ethanol, MA = methanol:glacial acetic acid (3:1). 
be dried before doing the touch or scrape preparative procedure. To guarantee cell adhesion to the glass, it is advisable to wait 30 $\mathrm{s}$ before placing the slides in the fixative. The preservation of the morphological and chemical characteristics of the tissue with this procedure would not be impaired since the material will not dry up. In any case, the quality of amplification is guaranteed, as shown in studies that demonstrated the use of material obtained from the skin of human patients with leishmaniasis that were first air dried and stained with Giemsa and then stored for up to 4 years without a coverslip (31). DNA extraction and amplification of Leishmania genes were possible even in cases in which cytologic analysis failed (31). Good results were also obtained with the amplification of Mycobacterium tuberculosis DNA obtained from air-dried sputum slides (13). The use of adhesive substances such as albumin and gelatin (30), silane, etc. is inadequate since the presence of any contaminating material should be avoided as much as possible when the objective is DNA extraction and amplification (23).

Logically, scrape preparatives would be expected to contain more cells and therefore to be more appropriate than touch preparatives, as actually indicated by our results. This agrees with literature data showing that fresh tissue scrape preparatives are more efficient than simple touch preparatives when evaluated by cytological methods for preoperative diagnosis $(10,23)$. The amount of DNA which can be extracted must therefore be larger in this type of material. However, despite the difference, the mean quantity of DNA extracted from all groups was much more than needed for PCR, which usually requires 50 to $100 \mathrm{ng}$, with the possibility of using only $5 \mathrm{ng}(32,33)$, or even than needed for Southern blotting, for which about 500 to $1000 \mathrm{ng}$ is necessary (32). This means that any of these forms of obtaining tissue samples can be utilized. Literature data agree with these results since epidemiological studies involving DNA extraction, quantification and amplification using oral mucosa washes or scrape preparatives (16) have demonstrated that the amount of cells, and consequently of DNA, obtained permits the identification of different genes amplified by PCR. Tumor touch preparatives have also been utilized, with or without fixation to obtain DNA and to amplify specific genes such as p53 $(34,35)$. As determined here, these cytologic methods are of low cost, easy to set up and execute, and can be utilized on a large-scale basis (16). These advantages are also taken into account when cells are to be obtained for cytologic analysis $(10,36)$ or even for fluorescent in situ hybridization (FISH).

Not only the method for material collection, but also the fixative is of fundamental importance. The present results show that $95 \%$ ethanol is superior to methanol:acetic acid. Ethanol at $14 \%$ concentration, i.e., a concentration much lower than the one used here, has been used in studies of DNA extraction from oral mucosa cells obtained by oral brushing or washing and the results obtained have shown that DNA is of sufficient quality and quantity for the determination of gene sequences of different sizes (16). Ethanol is also the fixative used for cytologic analysis $(10,36)$ and even for FISH $(37,38)$, showing potential for adequate preservation not only of the chemical characteristics of cell components, but also of their morphological aspect. Cells obtained in this manner can therefore be utilized for different types of analysis, a fact supporting the importance of the definition of a protocol such as the one used here.

PCR amplification was used for qualitative DNA determination, as also done in other studies (16). DNA amplification by multiplex PCR for AZF (Yq11) showed that both the fixatives and the materials yielded similar good quality results. It was possible to verify the integrity of specific genes by the presence and the quality of the electrophoretic bands. The results showed well-de- 
fined, strong bands positioned at the expected points for the amplified genes. In addition, there was no dispersal or migration of the material beyond or short of the expected points.

In conclusion, the proposed method of obtaining cells from autopsy cases fulfills the criteria for low cost, practicity and easy storage for a long time making it a good option for the analysis of congenital disorders mainly in places with few resources.

\section{Acknowledgments}

We wish to thank the Department of Genetics, FMRP-USP, and the residents of the Department de Pathology, HCFMRP-USP.

\section{References}

1. Keeling JW \& Boyd P (1993). Congenital malformation, prenatal diagnosis and fetal examination. In: Keeling JW (Editor), Fetal and Neonatal Pathology. 2nd edn. Springer Verlag, London, UK.

2. Maria e Silva J \& Manço AMRX (1998). Aspectos epidemiológicos da mortalidade infantil em Ribeirão Preto: Informativo Epidemiológico de Ribeirão Preto. Ano II, No. 24.

3. Peres LC (2000). Criação de um banco de dados de necropsias pediátricas realizadas no Hospital das Clínicas da Faculdade de Medicina de Ribeirão Preto da Universidade de São Paulo no período de abril de 1993 a abril de 1999. "Livre-Docente" thesis, Departamento de Patologia, Faculdade de Medicina de Ribeirão Preto, Universidade de São Paulo, Ribeirão Preto, SP, Brazil.

4. Pirmez C, Trajano VS, Neto MPO, Cruz AM, Costa SCG, Catanho M, Degrave W \& Fernandes O (1999). Use of PCR in diagnosis of human American tegumentary leishmaniasis in Rio de Janeiro, Brazil. Journal of Clinical Microbiology, 37: 1819-1823.

5. Ortolan D (2001). Estudo citogenético em crianças com anomalias congênitas submetidas a necropsia no Hospital das Clínicas da Faculdade de Medicina de Ribeirão Preto da Universidade de São Paulo, no período de novembro de 1996 a novembro de 1999. Master's thesis, Departamento de Genética e Matemática Aplicada à Biologia, Faculdade de Medicina de Ribeirão Preto, Ribeirão Preto, SP, Brazil.

6. de Launoit Y, Kiss R \& Danguy A (1990). Influence of smear preparation and fixatives on the ploidy and the morphonuclear features of the MXT-mammary tumor and normal tissues in the mouse. Cytometry, 11: 691-699.

7. Hutchinson ML, Agarwall P, Denault T, Berger B \& Cibas ES (1992). A new look at cervical cytology. Thinprep multicenter trial results. Acta Cytologica, 36: 499-504.

8. Geyer JW, Hancock F, Carrico C \& Kirkpatrick M (1993). Preliminary evaluation of Cyto-Rich: an improved automated cytology preparation. Diagnostic Cytopathology, 9: 417-422.

9. Avidor B, Varon M, Marmor S, Lifschitz-Mercer B, Kletter Y, Ephros $M$ \& Giladi $M$ (2001). DNA amplification for the diagnosis of catscratch disease in small quantity clinical specimens. American Journal of Clinical Pathology, 115: 900-909.

10. Blumenfeld W, Hashmi N \& Sagerman P (1998). Comparison of aspiration, touch and scrape preparations simultaneously obtained from surgically excised specimens - Effect of different methods of smear preparation on interpretative cytologic features. Acta Cytologica, 42: 1414-1418.

11. Greer CE, Lund JK \& Manos MM (1991). PCR amplification from paraffin embedded tissues: recommendations on fixatives for long- term storage and prospective studies. PCR Methods and Applications, 1: 46-50

12. Burton MP, Schneider BG, Brown R, Escamilla-Ponce N \& Gulley ML (1998). Comparison of histologic stains for use in PCR analysis of microdissected, paraffin embedded tissues. Biotechniques, 24: 86-92.

13. Patnaik M, Liegmann K \& Peter JB (2001). Rapid detection of smear-negative Mycobacterium tuberculosis by PCR and sequencing for rifampin resistance with DNA extracted directly from slides. Journal of Clinical Microbiology, 39: 51-52.

14. Mollaoglu N, Wilson MJ \& Cowpe JG (2001). Extraction of DNA from oral cytological samples by scrape preparatives and smear method suitable for restriction site mutation analysis: A pilot study. Diagnostic Cytopathology, 25: 83-85.

15. Tanigawara $Y$, Kita $T$, Hirono M, Sakaeda $T$, Komada $F$ \& Okumura $K$ (2001). Identification of $\mathrm{N}$-acetyltransferase 2 and CYP2C19 genotypes for hair, buccal cell swabs, or fingernails compared with blood. Therapeutic Drug Monitoring, 23: 341-346.

16. Garcia-Closas M, Egan KM, Abruzzo J et al. (2001). Collection of genomic DNA from adults in epidemiological studies by cytobrush and mouthwash. Cancer Epidemiology, Biomarkers and Prevention, 10: 687-696.

17. Dastigiri S, Stone DH, Le-Ha C \& Gilmour WH (2002). Prevalence and secular trend of congenital anomalies in Glasgow, UK. Archives of Diseases in Childhood, 86: 257-263.

18. Shibata D, Kurosu M \& Noguchi TT (1991). Fixed human tissues: a resource for the identification of individuals. Journal of Forensic Sciences, 36: 1204-1212.

19. Serth J, Kuczyk MA, Paeslack U, Lichtinghagen R \& Jonas U (2000). Quantitation of DNA extracted after micropreparation of cells from frozen and formalin-fixed tissue sections. American Journal of Pathology, 156: 1189-1196.

20. Kuykendall JR \& Bogdanffy MS (1992). Efficiency of DNA-histone crosslinking induced by saturated and unsaturated aldehydes in vitro. Mutation Research, 283: 131-136.

21. Mao Y, Wei W, Zhang J, Zhang S \& Rao X (2001). Real-time monitoring of formaldehyde-induced DNA-lysozyme cross-linking with piezoelectric quartz crystal impedance analysis. Analyst, 126: 15681572

22. Goldsworthy SM, Stockton PS, Trempus CS, Foley JF \& Maronpot RR (1999). Effects of fixation on RNA extraction and amplification from laser capture microdissected tissue. Molecular Carcinogenesis, 25: 86-91.

23. Ben-Ezra J, Johnson DA, Rossi J, Cook N \& Wu A (1991). Effect of 
fixation on the amplification of nucleic acids from paraffin-embedded material by polymerase chain reaction. Journal of Histochemistry and Cytochemistry, 39: 351-354.

24. Li J, Liao X \& Yang H (1999). Molecular characterization of a parasite tapeworm (Lígula) based on DNA sequences from formalin-fixed specimens. Biochemical Genetics, 38: 309-322.

25. Cawkwell L \& Quirke P (2000). Direct multiplex amplification of DNA from a formalin fixed, paraffin wax embedded tissue section. Journal of Clinical and Molecular Pathology, 53: 51-52.

26. Ingjer $F$ (1977). A method of correlating ultrastructural and histochemical data from individual muscle fibers. Histochemistry, 54: 169-172.

27. Van Noorden CJ \& Fredericks WM (1992). Enzyme Histochemistry: a Laboratory Manual of Current Methods. Oxford University Press, Oxford, UK.

28. Vogels IMC \& Van Noorden CJ (1993). Use of frozen biologic material for combined light and electron microscopy. Ultrastructural Pathology, 17: 537-546.

29. Prento $P$ (1997). The effects of freezing, storage and thawing on cell compartment integrity and ultrastructure. Histochemistry and Cell Biology, 108: 543-547.

30. Polack JM \& McGee JO (Editors) (1992). In Situ Hybridization: Principles and Practice. 2nd edn. Oxford University Press, New York.

31. Motazedian H, Karamian M, Noyes HA \& Ardehali S (2002). DNA extraction and amplification of Leishmania from archived, Giemsastained slides, for the diagnosis of cutaneous leishmaniasis by PCR.
Annals of Tropical Medicine and Parasitology, 96: 31-34.

32. Thompson MW, Mclnnes RR \& Willard HF (1993). Thompson \& Thompson. Genética Médica. 5th edn. Guanabara Koogan, Rio de Janeiro, RJ, Brazil.

33. McArthur M, Gerum S \& Stamatoyannopoulos G (2001). Quantification of DNAsel-sensitivity by real-time PCR: quantitative analysis of DNAsel-hypersensitivity of the mouse ß-globin LCR. Journal of Molecular Biology, 13: 327-334.

34. Kovach JS, McGovern RM, Cassady JD, Swanson SK, Wold LE, Volgestein B \& Sommer SS (1991). Direct sequencing from touch preparations of human carcinomas: analysis of p53 mutations in breast carcinomas. Journal of the National Cancer Institute, 83 : 1004-1009.

35. Ricevuto E, Ficorella C, Fusco C et al. (1996). Molecular diagnosis of p53 mutation in gastric carcinoma by touch preparation. American Journal of Pathology, 148: 405-413.

36. Shidham VB, Dravid NV, Grover S \& Kher AV (1984). Role of scrape cytology in rapid intraoperative diagnosis. Value and limitations. Acta Cytologica, 28: 477-482.

37. Huang SF, Hsu HC \& Fletcher JA (1999). Investigation of chromosomal aberrations in hepatocellular carcinoma by fluorescence in situ hybridization. Cancer Genetics and Cytogenetics, 111: 21-27.

38. Oliveira K, Haase G, Kurtzman C, Hyldig-Nielsen JJ \& Stender H (2001). Differentiation of Candida albicans and Candida dubliniensis by fluorescent in situ hybridization with peptide nucleic acid probes. Journal of Clinical Microbiology, 39: 4138-4141. 